\title{
Nutritional and pharmacological enhancement of gut-associated lymphoid tissue
}

\author{
M Keith Hanna MD, Kenneth A Kudsk MD
}

MK Hanna, KA Kudsk. Nutritional and pharmacological enhancement of gut-associated lymphoid tissue. Can J Gastroenterol 2000;14(Suppl D):145D-151D. There has been an explosion of research in the field of nutrition over the past quarter century. Clinical studies have demonstrated the effectiveness of providing nutrition by the enteral route in reducing septic morbidity in critically ill patients. These improved outcomes have been substantiated by animal models that show that enteral nutrition decreases gut permeability while maintaining the gut-associated lymphoid tissue (GALT) in mucosal immunity. Evidence points to the important immunological role of the gut in the maintenance of mucosal immunity at both intestinal and extraintestinal sites. The preservation of this mucosal immunity by enteral nutrition is consistent with the lower morbidity seen in severely injured patients who receive nutrition via the gastrointestinal tract. For patients who are unable to be fed by the enteral route and who require parenteral nutrition, several supplements show promise in enhancing the mucosal immune system defenses. The nutritional and pharmacological tactics that may enhance the GALT and thereby maintain mucosal immunity are examined.

Key Words: Bombesin; Enteral feedings; GALT; Glutamine; Mucosal immunity; Neuropeptides; Parenteral feedings; Pneumonia

\section{Stimulation nutritionnelle et pharmacologique du système lymphoïde du tube digestif}

RÉSUMÉ : Dans le domaine de la nutrition, on a assisté à un foisonnement de projets de recherche au cours des 25 dernières années. Des études cliniques ont montré l'efficacité de la nutrition entérale à réduire la morbidité septique chez les grands malades. Ces résultats favorables, ont été confirmés par des modèles animaux qui révèlent que la nutrition entérale réduit la perméabilité intestinale, tout en maintenant l'immunité muqueuse du système lymphoïde du tube digestif. Les résultats soulignent l'importance du rôle immunologique de l'intestin dans le maintien de l'immunité muqueuse, tant intestinale qu'extra-intestinale. La préservation de cette immunité muqueuse par la nutrition entérale concorde avec une baisse de la morbidité observée chez les grands malades qui reçoivent leur alimentation par le tractus gastro-intestinal. Pour les patients qui sont incapables de se nourrir par la bouche et qui ont besoin de nutrition parentérale, plusieurs suppléments se révèlent prometteurs en ce sens qu'ils rehaussent les défenses du système immunitaire muqueux. On examine ici les tactiques nutritionnelles et pharmacologiques qui peuvent stimuler le système lymphoïde du tube digestif et maintenir ainsi l'immunité muqueuse.
$\mathrm{F}$ or many years, nutritional support has been recognized as an important factor in recovery from critical illness. Insights into the severe catabolism and immune suppression accompanying severe illness have paralleled the accumula- tion of knowledge of the physiological and biochemical aspects of the metabolic response to injury (1-7). This hypermetabolic state, observed in critically ill patients, progressively exhausts body protein and fat stores, and this

This mini-review was prepared from a presentation made at the World Congress of Gastroenterology, Vienna, Austria, September 6 to 11, 1998 Department of Surgery, The University of Tennessee, Memphis, Tennesse, USA

Correspondence: Dr KA Kudsk, 956 Court Avenue, Suite E228, Memphis, Tennesse 38163, USA. Telephone 901-448-8370, fax901-448-7306, kkudsk@utmem.edu

Received for publication June 14, 1999. Accepted June 23, 1999 
progressive, gradual malnutrition results in increased infection rates (8) and interference with wound healing (9). Critical illness and critical injury impair normal oral intake so that specialized nutritional support is necessary to provide the essential nutrients, vitamins and minerals, in addition to providing adequate calories and protein to meet energy and nitrogen requirements. Over the past 30 years, clinical and laboratory research has confirmed the ability of parenteral and enteral nutrition to provide these nutrients, but it has also demonstrated that there is a benefit gained when nutrients are delivered via the gastrointestinal tract that are not gained with parenteral nutrition. In addition, certain pharmaconutrients also appear to be effective in this regard. This article reviews the clinical and laboratory data that have demonstrated the advantages of enteral nutrition and the effect of adding specialty pharmaconutrients such as glutamine and neuropeptides to the therapeutic regimen.

\section{BACKGROUND}

In 1968, Dudrick et al (10) published landmark work that provided a clinical solution for nutritional support to patients with a nonfunctioning gastrointestinal tract by demonstrating the ability to provide adequate nutrition through the parenteral route. In patients who experience total loss of gut functioning, this therapy is life-saving. In severely malnourished patients (11), perioperative nutrition decreases the number of both infectious and noninfectious complications. However, several prospective, randomized clinical studies of severely injured patients have demonstrated an increase in the the number of infections of moist mucosal surfaces - pneumonia and/or intra-abdominal abscess - in patients fed parenterally compared with patients fed enterally in the early postinjury period (12-15). These findings have been confirmed in several laboratory models. Between 1981 and 1983, Kudsk et al $(16,17)$ demonstrated significant differences in mortality rate when malnourished or wellnourished rats were fed identical nutrient solutions parenterally or via gastrostomy for 12 days before an intraperitoneal injection of a hemoglobin-Escherichia coli suspension. Mortality rate at $48 \mathrm{~h}$ following the onset of peritonitis (17) dropped from $80 \%$ in parenterally fed animals to $40 \%$ in animals fed via the gastrointestinal tract. Clinical studies verify the efficacy of enteral nutrition in patients with burns (18) and in patients undergoing general surgical procedures, in addition to trauma patients (19-21). The present article reviews the apparent role of the gut in these defenses.

\section{THE GASTROINTESTINAL BARRIER}

The gut remains in constant contact with potential pathogens and toxic substances. While allowing absorption of nutrients across the mucosal surface, the gut is able to maintain an effective barrier against these hazardous agents. Bacterial translocation, the passage of intraluminal bacteria across the gastrointestinal mucosal barrier to mesenteric lymph nodes or other organs, appears to occur secondary to the overgrowth of pathogenic bacteria, host immunosuppression or physical impairment of the gut mucosa (22), although the importance of this phenomenon in humans remains controversial (23). Experimentally, malnutrition alone does not disrupt the mucosal barrier; however, the addition of an inflammatory site to pre-existing malnutrition dramatically increases bacterial translocation (24). Surprisingly, bacterial translocation occurs in approximately two-thirds of animals receiving parenteral nutrition alone. Bacterial translocation is reduced when the parenteral formula is provided via the gastrointestinal tract and almost completely eliminated when a complex enteral diet is administered (25). Experimentally, conditions that increase bacterial translocation also increase gut mucosal permeability to macromolecules (26). Although some clinical conditions, such as severe shock, result in increased bacterial translocation and gut mucosal permeability to macromolecules, a clear link to extraintestinal infectious complications such as pneumonia, remains elusive, and recent attention has been turned to the possible role of gut-associated lymphoid tissue (GALT) in the etiology of these infectious complications.

\section{GALT AND MUCOSAL IMMUNITY}

The mucosa is in constant contact with the external environment, and the mucosal surface requires protection against invasive infection. Nonimmunological protective mechanisms include intact tight junctions between adjacent epithelial cells, lactoferrin, defensins, rapid cell turnover, intestinal motility, gastric acid production, pancreatic enzyme secretion, mucin and an indigenous microbial flora that keeps bacterial overgrowth in check. Immunological protective mechanisms exist in the form of GALT, which consists of three main areas of lymphoid tissue: the Peyer's patches, lamina propria and intraepithelial lymphocytes. Interspersed among GALT cells are macrophages, dendritic cells, the enteric nervous system and other immune cells. The Peyer's patches consist of approximately 150 organized aggregates of lymphoid tissue within the small bowel and constitute the surveillance system for GALT. As antigen is taken up by the specialized M cells that overlie the Peyer's patches, these antigens are processed by dendritic cells and other antigenprocessing cells to stimulate circulating naive $\mathrm{B}$ and $\mathrm{T}$ cells that continually traffic through the Peyer's patches by way of adhesion molecules on the high endothelial venule. After committing to antigen specificity, these B and $\mathrm{T}$ cells migrate to mesenteric lymph nodes, proliferate, and eventually gain access to the vascular system by way of the thoracic duct (27). These sensitized cells migrate to the lamina propria immediately beneath the mucosal epithelial surfaces throughout the body where B cells mature into plasma cells and $\mathrm{T}$ cells produce the cytokines that regulate immunoglobulin $\mathrm{A}$ ( IgA) production and other intestinal functions (28). IgA production is a balance between two types of $\mathrm{T}$ helper ( $\mathrm{Th}$ ) cell populations. Interferon gamma (IFN- $\gamma$ ) and tumour necrosis factor-beta (TNF- $\beta$ ) (or lymphotoxin) are cytokines that inhibit IgA production and are formed by Th1 type cells. Interleukin (IL)-4, IL-5, IL-6 and IL-10 stimulate IgA production and are produced by Th2 type cells (29). The intraepithelial lymphocytes are a diverse population of cells 


\section{COPYRIGHT PULSUS GROUP INC, - DO NOT COPY}

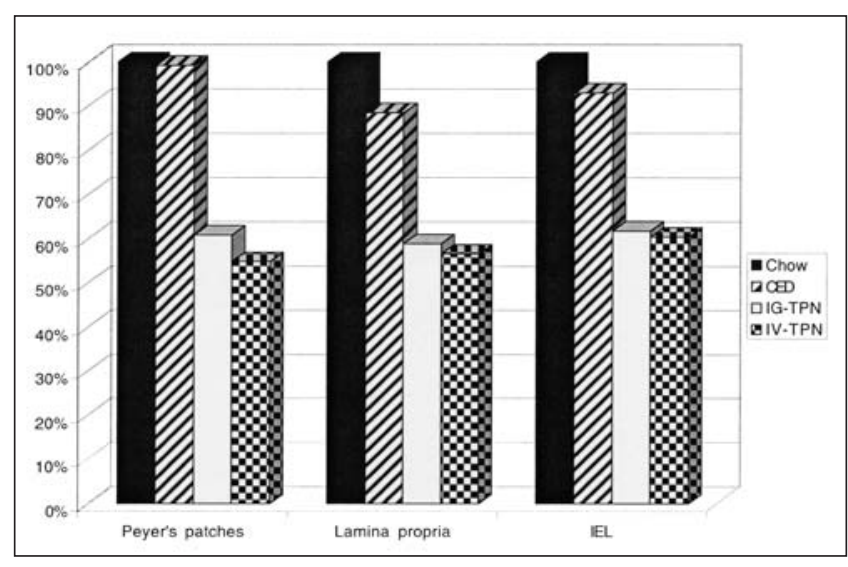

Figure 1) Percentage of recovery of total cells in gut-associated lymphoid tissue after receiving mouse chow, intravenous total parenteral nutrition (IV-TPN), intragastric TPN (IG-TPN) or a complex enteral diet (CED). IEL Intraepithelial lymphocytes

consisting of mass cells, natural killer cells and cytotoxic T cells that reside within the mucosal epithelium. While their specific function remains unclear, they appear to influence mucosal permeability and be important in tolerance (30).

Sensitized B and T cells that are released from the thoracic duct into the vascular system also migrate to extraintestinal mucosal sites such as the respiratory tract, mammary gland, genitourinary tract and salivary glands. The entire system of these lymphoid cells at different mucosal sites is termed the mucosal-associated lymphoid tissue (MALT) and is relevant in that antigens processed within the gastrointestinal tract can provide protection against antigens at other mucosal sites. Although some animal species appear to have nasal-associated lymphoid tissue that can also serve as a surveillance organ for mucosal antigens, the presence and importance of such organs have not been confirmed in humans.

GALT comprises approximately $50 \%$ of the immune system within the body and is responsible for over $70 \%$ of the immunoglobulin production by the body (31) in the form of $\operatorname{IgA}$. IgA is immediately transported to the epithelial surface after it is produced by the plasma cells in association with a secretory component expressed on the basal membrane of the overlying mucosal cell. The secretory component provides protection against proteolysis by bacteria (32). Within the lumen, IgA binds to intraluminal bacteria, preventing their attachment to the mucosal epithelium (31) and a critical initial step in invasive infection. GALT provides the main immunological protection for mucosal surfaces of the body with one of its primary functions being to prevent invasive infection and to assist in preserving normal colonization patterns.

\section{THE TYPE AND ROUTE OF NUTRITIONAL} SUPPORT AFFECT GALT CELL POPULATIONS

With the obvious importance of GALT in maintaining immunological protection, attention focuses on the changes in GALT that occur in association with different forms of nutrition. In animal models, GALT is extremely sensitive to

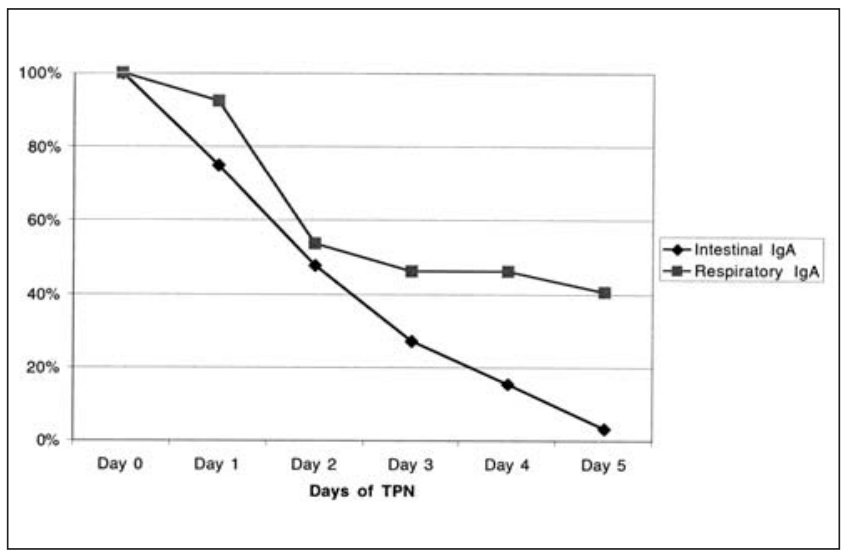

Figure 2) Percentage decrease of intestinal and respiratory immunoglobulin A ( $\operatorname{IgA}$ ) levels with intravenous total parenteral nutrition (TPN)

the type and route of nutritional support, which affects the size and character of GALT, as well as its ability to function as a defensive force in mucosal immunity.

Cell changes within GALT: Parenteral nutrition and the lack of enteral delivery of nutrients significantly affect GALT cell populations within the Peyer's patches, lamina propria and intraepithelial space in mice (33). Lymphocyte recovery remains normal in mice receiving mouse chow or any one of several complex enteral diets containing various proportions of fat, protein and carbohydrate. Parenteral feeding, however, diminishes GALT cell populations by approximately $40 \%$ (Figure 1). Surprisingly, the administration of intragastric (IG) total parenteral nutrition (TPN) solution, as a control for parenteral nutrition and to mimic an elemental diet, also leads to GALT cell atrophy. These decreases in GALT lymphocytes occur in B cell and T cell populations with a significant reduction in the CD4/CD8 ratio within the lamina propria. GALT is an extremely dynamic organ with significant decreases occuring in all cell populations within two days of the institution of parenteral nutrition (34). Cell populations reach their lowest levels by the third day. Recovery is also rapid and total cell yields, and $T$ and $B$ cell yields return to normal in the Peyer's patches and lamina propria within two days of reinstituting chow feeding, with the eventual recovery of the CD4/CD8 ratio after four days of chow refeeding.

Functional consequences of GALT cell changes: The results of GALT cell population changes with dietary manipulation carry functional consequences for the mucosal immunity. IgA levels within the intestinal and respiratory tract rapidly decline after the institution of parenteral nutrition, in parallel with GALT cell changes (Figure 2) (33). The effect of these IgA decreases can be demonstrated using a mouse-adapted influenza virus, the A/PR8 (H1N1) virus. Defenses against the H1N1 virus is IgA mediated, and immunity can be established shortly after primary intranasal immunization. Within two weeks, rechallenge with the virus results in rapid clearance of the virus from the upper respiratory tract (35). After establishing immunity in a group of 


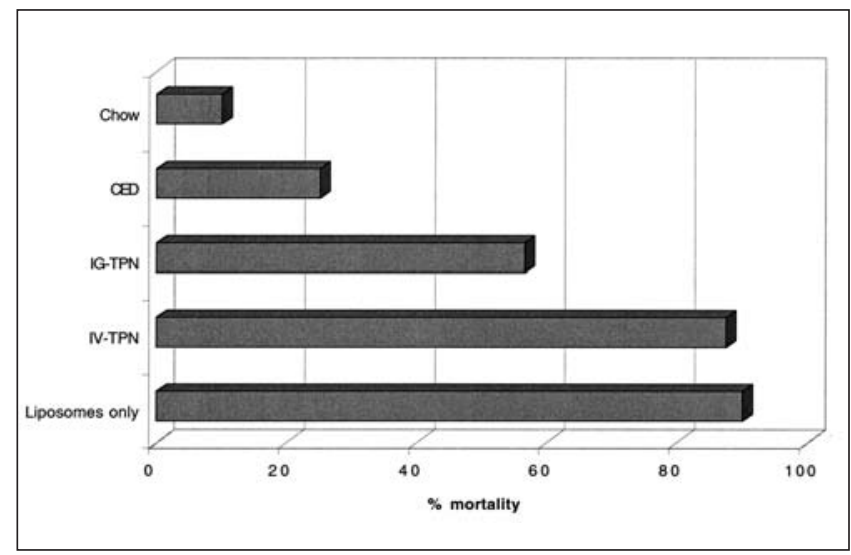

Figure 3) Mortality rates due to Pseudomonas bacteria in previously immunized mice after receiving mouse chow, complex enteral diet (CED), intragastric total parenteral nutrition (IG-TPN) or intravenous TPN (IV-TPN) compared with those in unimmune mice given liposomes only

mice and confirming effective immunization with serum IgG levels, mice randomly selected to receive mouse chow or complex enteral diets demonstrated intact IgA-mediated respiratory defenses to a rechallenge with the virus. Approximately $50 \%$ of mice receiving parenteral nutrition lost this defense and continued to have positive upper respiratory tract viral cultures $40 \mathrm{~h}$ after rechallenge. Surprisingly, mice randomly assigned to IG-TPN maintained normal mucosal immunity and cleared the virus effectively despite GALT cell changes.

A defect with IG-TPN was suspected due to GALT atrophy, but it required a virulent bacterial model to demonstrate impaired immunity in this group. Pseudomonas aeruginosa is frequently cultured from patients in intensive care units, and pneumonia with this organism carries a mortality rate as high as $50 \%(36,37)$. Abraham et al (38) successfully immunized mice against $P$ aeruginosa pneumonia by intranasal inoculation of pseudomonas polysaccharide antigen in liposomes. This intranasal immunization stimulated specific antipseudomonal IgA responses and resulted in a reduction in mortality rate to a subsequent intratracheal challenge of Pseudomonas species. We confirmed this work, showing that prior immunization with Pseudomonas antigen in liposomes reduced mortality from $90 \%$ in nonimmune animals following an intratracheal challenge of $1.2 \times 10^{8}$ $P$ aeruginosa organisms to $10 \%$ with immunity. Diet also affected this immunity. Following immunization, mice that were randomly assigned to mouse chow or a complex enteral diet survived a subsequent challenge with a mortality rate of $10 \%$ to $20 \%$. Parenteral nutrition completely robbed animals of their immunity, resulting in mortality rates equal to those of unimmunized animals (Figure 3). IG-TPN maintained some, but not all immunity, with a survival rate midway between that of animals fed mouse chow and that of animals fed parenteral nutrition (39). Enteral feeding significantly influences extraintestinal mucosal defenses compared with parenteral nutrition, but the type of enteral diet influences the effectiveness of this mucosal defense.
Cytokine changes influenced by route and type of nutrition: TPN-associated IgA depression can be explained by cytokine changes occurring within GALT. As mentioned previously, IgA production is mediated by cytokines released from T cells within GALT (40). These cytokines are grouped based on their ability to downregulate (Th1 cytokines: IFN- $\gamma$ and TNF- $\beta$ ) or upregulate (Th2 cytokines: IL-4, IL-5, IL-6 and IL-10) IgA production (41). Parenteral nutrition significantly depressed both IL-4 and IL-10 cytokine levels in homogenates of small intestinal gut samples compared with normal levels in chow animals fed a complex enteral diet. IG-TPN depressed only the IL-4 levels, not the IL-10 levels. IL-5, IL- 6 and IFN- $\gamma$ levels remained unchanged by dietary manipulation, resulting in two important IgA-stimulating cytokines, IL-4 and IL-10, being unbalanced with parenteral nutrition. The depression of the Th2 cytokines, IL-4 and IL10 , correlated significantly with IgA levels and the impaired mucosal immunity with parenteral nutrition.

Summary: The lack of complex enteral feeding causes rapid cellular changes in GALT that are reversible with the reinstitution of enteral feeding. Changes in intestinal cytokine levels were correlated with decreases in IgA levels within the intestine. A functional effect of this decline was a depression in both respiratory and intestinal IgA levels, resulting in an impairment of IgA-mediated immunity against both viruses and bacteria. Administration of feeding via the gut - even an inadequate diet - provides some mucosal immunity, but complete protection is provided when the gut is stimulated by complex diets that maximally stimulate GALT cell populations, IgA production and normal mucosal barriers.

\section{ADJUNCTS OF PARENTERAL NUTRITION INFLUENCE MUCOSAL IMMUNITY}

Many clinical conditions such as short bowel syndrome, fistulas, and lack of enteral access preclude the ability to provide adequate nutrition via the gastrointestinal tract and require parenteral nutrition. The clinical and laboratory evidence of impaired immunity with parenteral nutrition warrant the search for supplements capable of preserving GALT mass, and respiratory and intestinal tract defenses against infection. We have examined the GALT immunostimulatory effects of glutamine, which is the preferred substrate for enterocytes and proliferating lymphocytes $(42,43)$, and studied enteric nervous system products such as neuropeptides.

Glutamine: Glutamine is the most prevalent amino acid in the blood and cell cytosol, and is an essential precursor for the synthesis of nucleic acids in all cells (44). It is an important fuel source for enterocytes as well as numerous immunological cells including lymphocytes, macrophages and neutrophils $(42,43,45-47)$. Clinically, glutamine production rapidly increases during times of stress and sepsis in association with decreased cellular and serum levels so that it is considered an essential amino acid under these conditions (48). Clinical supplementation of parenteral nutrition with glutamine reduces bacteremia and normalizes gastrointestinal colonization patterns in bone marrow transplant patients, 
implying that glutamine helps to maintain host defenses (49). Experimentally, glutamine attenuates atrophy of the small intestine and colonic mucosa associated with parenteral nutrition (50) while decreasing intestinal permeability (51) and bacterial translocation (52) under similar conditions.

Parenteral solution supplemented with $2 \%$ glutamine or the dipeptide, glycyl-L-glutamine, for five days preserves GALT cell mass within the Peyer's patches, the lamina propria and intraepithelial space, and maintains the normal lamina propria CD4/CD8 ratio and intestinal IgA levels $(53,54)$. Using the functional infectious challenge, glutamine supplementation also significantly improves IgAmediated defenses against the $\mathrm{H} 1 \mathrm{~N} 1$ virus $(53,54)$ and significantly improves mortality to pseudomonas pneumonia when compared with unsupplemented parenteral nutrition (30). Although glutamine significantly improves all parameters of mucosal function - both histological and functional improvement fails to reach the level of chow-fed animals, implying incomplete maintenance of IgA-mediated mucosal immunity (Figure 4).

Neuropeptides from the enteric nervous system: The enteric nervous system (ENS) pervades the gastrointestinal tract with approximately $2 \mathrm{~m}$ of nervous tissue $/ \mathrm{mm}^{3}$ of intestine (30). The ENS has been postulated to regulate gut motility, endocrine and exocrine functions of the gastrointestinal tract, and microcirculatory changes in the bowel $(55,56)$ in addition to influencing the immune system $(57,58)$. These neurons release neuropeptides such as gastrin-releasing peptide (GRP), cholecystokinin, neurotensin and gastrin. Earlier investigators noted that bombesin, a tetradecapeptide isolated from the skin of amphibians, and an analogue of GRP in humans, stimulated intestinal IgA levels and reduced bacterial translocation. Bombesin stimulates the release of all gut neuropeptides, except secretin, while inducing the release of gastric, pancreatic and intestinal secretions (59).

Bombesin supplementation prevents all deleterious effects of parenteral nutrition in the murine model. Bombesin supplementation of parenteral nutrition averted all GALT cell mass changes, and loss of IgA-mediated antiviral and antibacterial defenses induced by intravenous TPN alone. It prevented the reduction in $\mathrm{T}$ and $\mathrm{B}$ cells throughout the GALT, but preserved respiratory and intestinal IgA levels. Both $T$ cell number and CD4/CD8 ratio were maintained in the lamina propria and intraepithelial space. This neuropeptide also reverses the changes induced with five days of parenteral nutrition. The addition of bombesin to parenteral nutrition returned both GALT cell atrophy, and respiratory and intestinal IgA levels to normal within three days (60). Established immunity to the $\mathrm{H} 1 \mathrm{~N} 1$ virus (61) and $P$ aeruginosa (unpublished data) was comparable with that of chowfed animals.

GRP receptors have been found on circulating lymphocytes as well as in the upper respiratory tract of humans. Administration of bombesin to humans stimulates a protein-rich secretion by the nasal mucosa. It is unclear whether it is bombesin or other neuropeptides released in re-

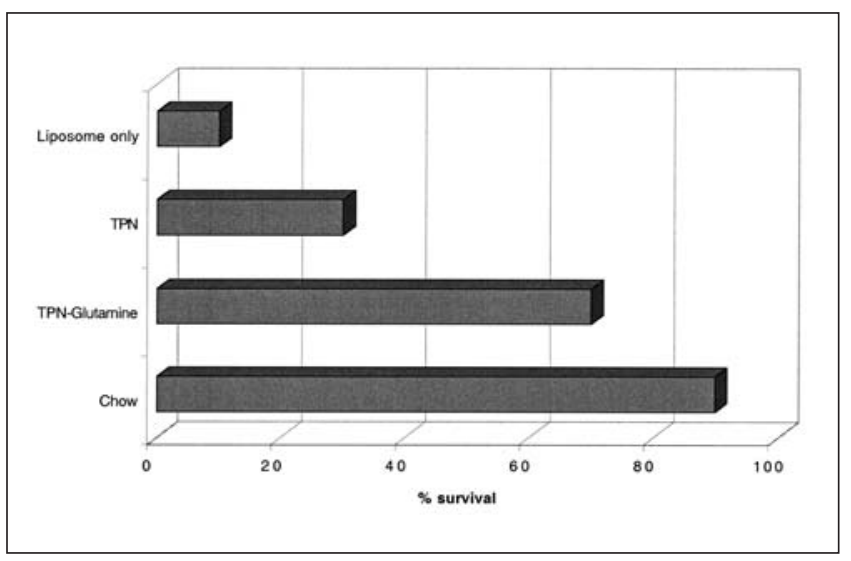

Figure 4) Survival rates of mice previously immunized with Pseudomonas bacteria, after receiving mouse chow, standard intravenous total parenteral nutrition (TPN) or TPN supplemented with glutamine (TPN-glutamine) compared with those of unimmunized animals (liposomes only)

sponse to bombesin administration that upregulate the mucosal immunity.

Summary: Glutamine and the neuropeptide bombesin prevent the deleterious effects of parenteral nutrition on GALT and mucosal immunity. Their ability to manipulate mucosal immunity suggests that it is the lack of enteral stimulation rather than any toxic effect of the parenteral solution that creates the deleterious effects on mucosal immunity noted in animal models and clinical circumstances. The potential for a nutritional supplement capable of maintaining antiviral and antibacterial defenses in patients who are unable to take enteral solution may provide protection against bacterial invasion without the use of antibiotics and is an exciting prospect.

\section{CONCLUSIONS}

Mucosal immunity is affected by the route and type of nutrients provided. This relationship has been clinically substantiated by the reduction in infectious complications in critically ill and critically injured patients who received a complex enteral diet. This relationship has been studied experimentally, and a correlation has been established between enteral delivery of nutrients and the maintenance of GALT cell populations, secretory IgA levels, antiviral and antibacterial mucosal immunity and IgA-mediating cytokine levels. Specific nutrients such as glutamine and neuropeptides provide similar advantages when supplemented with parenteral nutrition. Clinical benefits may originate from the specific nutrients provided and by direct stimulation of the ENS, which releases neuropeptides capable of exerting immunological effects. The potential clinical applications are immense.

ACKNOWLEDGEMENT: Supported in part by grant 5R01 6M53439 from the National Istitutes of Health, Bethesda, Maryland. 


\section{REFERENCES}

1. Cuthbertson D. Further observations on the disturbance of metabolism caused by injury, with particular reference to the dietary requirements of fracture cases. Br J Surg 1935-6;23:505-20.

2. Elwyn DH. Nutritional requirements of adult surgical patients. Crit Care Med 1980;8:9-20.

3. Long CL, Schaffel N, Geiger JW, Schiller WR, Blakemore WS. Metabolic response to injury and illness: estimation of energy and protein needs from indirect calorimetry and nitrogen balance. JPEN J Parenter Enteral Nutr 1979;3:452-6.

4. Nelson KM, Long CL. Physiological basis for nutrition in sepsis. Nutr Clin Pract 1989;4:6-15.

5. Cerra FB, Siegel JH, Coleman B, Border JR, McMenamy RR. Septic autocannibalism. A failure of exogenous nutritional support. Ann Surg 1980;192:570-80.

6. Shaw JH, Wildbore M, Wolfe RR. Whole body protein kinetics in severely septic patients. The response to glucose infusion and total parenteral nutrition. Ann Surg 1987;205:288-94.

7. Pomposelli JJ, Flores EA, Bistrian BR. Role of biochemical mediators in clinical nutrition and surgical metabolism. JPEN J Parenter Enteral Nutr 1988;12:212-8.

8. Polk HC, Fry D, Flint LM. Dissemination and causes of infection. Surg Clin North Am 1976;56:817-29.

9. Garrow JS. Protein nutrition and wound healing. Proc Nutr Soc 1969;28:242-8.

10. Dudrick SJ, Wilmore DW, Vars HM, Rhoads JE. Long-term total parenteral nutrition with growth, development, and positive nitrogen balance. Surgery 1968;64:134-42.

11. Perioperative total parenteral nutrition in surgical patients. The Veterans Affairs Total Parenteral Nutrition Cooperative Study Group. N Engl J Med 1991;325:525-32.

12. Kudsk KA, Croce MA, Fabian TC, et al. Enteral versus parenteral feeding. Effects on septic morbidity after blunt and penetrating abdominal trauma. Ann Surg 1992;215:503-13.

13. Kudsk KA, Minard G, Croce MA, et al. A randomized trial of isonitrogenous enteral diets after severe trauma. An immuneenhancing diet reduces septic complications. Ann Surg 1996;224:531-43.

14. Moore FA, Moore EE, Jones TN, McCroskey BL, Peterson VM. TEN versus TPN following major abdominal trauma - reduced septic morbidity. J Trauma 1989;29:916-23.

15. Moore EE, Jones TN. Benefits of immediate jejunostomy feeding after major abdominal trauma - a prospective, randomized study. J Trauma 1986;26:874-81.

16. Kudsk KA, Carpenter G, Petersen S, Sheldon GF. Effect of enteral and parenteral feeding in malnourished rats with $E$ coli-hemoglobin adjuvant peritonitis. J Surg Res 1981;31:105-10.

17. Kudsk KA, Stone JM, Carpenter G, Sheldon GF. Enteral and parenteral feeding influences mortality after hemoglobin-E coli peritonitis in normal rats. J Trauma 1983;23:605-9.

18. Herndon DN, Barrow RE, Stein M, et al. Increased mortality with intravenous supplemental feeding in severely burned patients. J Burn Care Rehabil 1989;10:309-13.

19. Daly JM, Lieberman MD, Goldfine J, et al. Enteral nutrition with supplemental arginine, RNA, and omega-3 fatty acids in patients after operation: immunologic, metabolic, and clinical outcome. Surgery 1992;112:56-67.

20. Daly JM, Weintraub FN, Shou J, Rosato EF, Lucia M. Enteral nutrition during multimodality therapy in upper gastrointestinal cancer patients. Ann Surg 1995;221:327-38.

21. Braga M, Vignali A, Mari G, et al. Peri-operative immunonutrition improves outcome in cancer surgical patients. Presented at the Eighteenth Annual Meeting of the Surgical Infection Society, New York, April 30, 1998.

22. Mainous MR, Block EF, Deitch EA. Nutritional support of the gut: how and why. New Horiz 1994;2:193-201.

23. Deitch EA. Bacterial translocation of the gut flora. J Trauma 1990;30:S184-9.

24. Deitch EA, Winterton J, Li M, Berg R. The gut as a portal of entry for bacteremia. Role of protein malnutrition. Ann Surg 1987;205:681-92.

25. Alverdy JC, Aoys E, Moss GS. Total parenteral nutrition promotes bacterial translocation from the gut. Surgery 1988;104:185-90.

26. Purandare S, Offenbartl K, Westrom B, Bengmark S. Increased gut permeability to fluorescein isothiocyanate-dextran after total parenteral nutrition in the rat. Scand J Gastroenterol 1989;24:678-82.
27. Kelsall BS. Gut-associated lymphoid tissue antigen handling and T-lymphocyte response. In: Ogra PL, Lamm ME, Strober W, Bienenstock J, McGhee JR, eds. Mucosal Immunology. San Diego: Academic Press, 1999:293-317.

28. McIntyre TS. Gut-associated lymphoid tissue regulation of IgA B-cell development. In: Ogra PL, Lamm ME, Strober W, Bienenstock J, McGhee JR, eds. Mucosal Immunolgy. San Diego: Academic Press, 1999:319-56.

29. Lebman DC. Cytokines in the mucosal immune system. In: Ogra PL, McGhee JR, Mestecky J, Strober W, Bienenstock J, eds. Handbook of Mucosal Immunology. San Diego: Academic Press, 1994:243-9.

30. Ottaway CA. Neuroimmunomodulation in the intestinal mucosa. Gastroenterol Clin North Am 1991;20:511-29.

31. Svanborg C. Bacterial adherence and mucosal immunity. In: Ogra PL, McGhee JR, Mestecky J, Strober W, Bienenstock J, eds. Handbook of Mucosal Immunology. San Diego: Academic Press, 1994:71-8.

32. Underdown BM. Mucosal immunoglobins. In: Ogra PL, McGhee JR, Mestecky J, Strober W, Bienenstock J, eds. Handbook of Mucosal Immunology. San Diego: Academic Press, 1994:79-97.

33. Li J, Kudsk KA, Gocinski B, Dent D, Glezer J, Langkamp-Henken B. Effects of parenteral and enteral nutrition on gut-associated lymphoid tissue. J Trauma 1995;39:44-52.

34. King BK, Li J, Kudsk KA. A temporal study of TPN-induced changes in gut-associated lymphoid tissue and mucosal immunity. Arch Surg 1997;132:1303-9.

35. Renegar KB, Small PA. Immunoglobulin A mediation of murine nasal anti-influenza virus immunity. J Virol 1991;65:2146-8.

36. Jarvis WR. Selected aspects of the socioeconomic impact of nosocomial infections: morbidity, mortality, cost, and prevention. Infect Control Hosp Epidemiol 1996;17:552-7.

37. Crouch Brewer S, Wunderink RG, Jones CB, Leeper KV. Ventilator-associated pneumonia due to Pseudomonas aeruginosa. Chest 1996;109:1019-29.

38. Abraham E, Shah S. Intranasal immunization with liposomes containing IL-2 enhances bacterial polysaccharide antigenspecific pulmonary secretory antibody response. J Immunol 1992;149:3719-26.

39. King BK, Kudsk KA, Li J, Wu Y, Renegar KB. Route and type of nutrition influence mucosal immunity to bacterial pneumonia. Ann Surg 1999;229:272-8.

40. Mosmann TR, Coffman RL. TH1 and TH2 cells: different patterns of lymphokine secretion lead to different functional properties. Annu Rev Immunol 1989;7:145-73.

41. Kramer DR, Sutherland RM, Bao S, Husband AJ. Cytokine mediated effects in mucosal immunity. Immunol Cell Biol 1995;73:389-96.

42. Windmueller HG, Spaeth AE. The Journal of Biological Chemistry, Volume 249, 1974: Uptake and metabolism of plasma glutamine by the small intestine. Nutr Rev 1990;48:310-2.

43. Souba WW. Glutamine: A key substrate for the splanchnic bed. Annu Rev Nutr 1991;11:285-308.

44. Voet D, Voet J. Nucleotide metabolism. In: Voet D, Voet J, eds. Biochemistry. New York: John Wiley and Sons Inc, 1995:795-828.

45. Wu G, Flynn NE. Regulation of glutamine and glucose metabolism by cell volume in lymphocytes and macrophages. Biochim Biophys Acta 1995; $1243: 343-50$.

46. O'Riordain MG, Fearon KC, Ross JA, et al. Glutamine-supplemented total parenteral nutrition enhances T-lymphocyte response in surgical patients undergoing colorectal resection. Ann Surg 1994;220:212-21.

47. Curi TC, de Melo MP, de Azevedo RB, Curi R. Glutamine utilization by rat neutrophils. Biochem Soc Trans 1997;25:249S.

48. Hall JC, Heel K, McCauley R. Glutamine. Br J Surg 1996;83:305-12.

49. Ziegler TR, Young LS, Benfell K, et al. Clinical and metabolic efficacy of glutamine-supplemented parenteral nutrition after bone marrow transplantation. A randomized, double-blind, controlled study. Ann Intern Med 1992;116:821-8.

50. O'Dwyer ST, Smith RJ, Hwang TL, Wilmore DW. Maintenance of small bowel mucosa with glutamine-enriched parenteral nutrition. JPEN J Parenter Enteral Nutr 1989;13:579-85.

51. Li J, Langkamp-Henken B, Suzuki K, Stahlgren LH. Glutamine prevents parenteral nutrition-induced increases in intestinal permeability. JPEN J Parenter Enteral Nutr 1994;18:303-7.

52. Burke DJ, Alverdy JC, Aoys E, Moss GS. Glutamine-supplemented 
total parenteral nutrition improves gut immune function. Arch Surg 1989;124:1396-9.

53. Li J, Kudsk KA, Janu P, Renegar KB. Effect of glutamine-enriched total parenteral nutrition on small intestinal gut-associated lymphoid tissue and upper respiratory tract immunity. Surgery 1997;121:542-9.

54. Li J, King BK, Janu PG, Renegar KB, Kudsk KA. Glycyl-L-glutamineenriched total parenteral nutrition maintains small intestine

gut-associated lymphoid tissue and upper respiratory tract immunity. JPEN J Parenter Enteral Nutr 1998;22:31-6.

55. Goyal RK, Hirano I. The enteric nervous system. N Engl J Med 1996;334:1106-15.

56. Debas HT, Mulvihill SJ. Neuroendocrine design of the gut. Am J Surg 1991;161:243-9.

57. Sternberg EM, Chrousos GP, Wilder RL, Gold PW. The stress response and the regulation of inflammatory disease. Ann Intern Med 1992;117:854-66.

58. Bienenstock J, Perdue M, Stanisz A, Stead R. Neurohormonal regulation of gastrointestinal immunity. Gastroenterology 1987;93:1431-4.

59. Greely GH. Enteric bombesin-like peptides. In: Thompson JC, Rayfer PL, Townsend CM, eds. Gastrointestinal Endocrinology. New York: McGraw-Hill Book Co, 1987:322-9.

60. Li J, Kudsk KA, Hamidian M, Gocinski BL. Bombesin affects mucosal immunity and gut-associated lymphoid tissue in intravenously fed mice. Arch Surg 1995;130:1164-70.

61. Janu PG, Kudsk KA, Li J, Renegar KB. Effect of bombesin on impairment of upper respiratory tract immunity induced by total parenteral nutrition. Arch Surg 1997;132:89-93. 


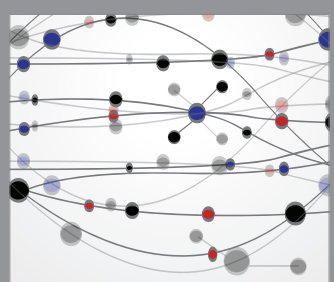

The Scientific World Journal
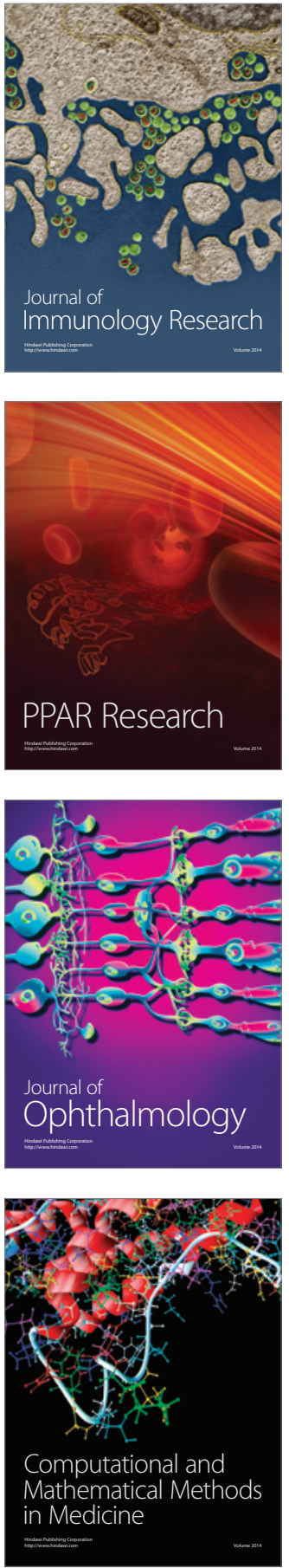

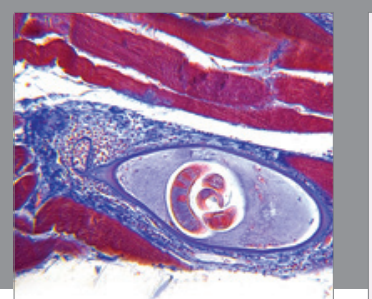

Gastroenterology Research and Practice

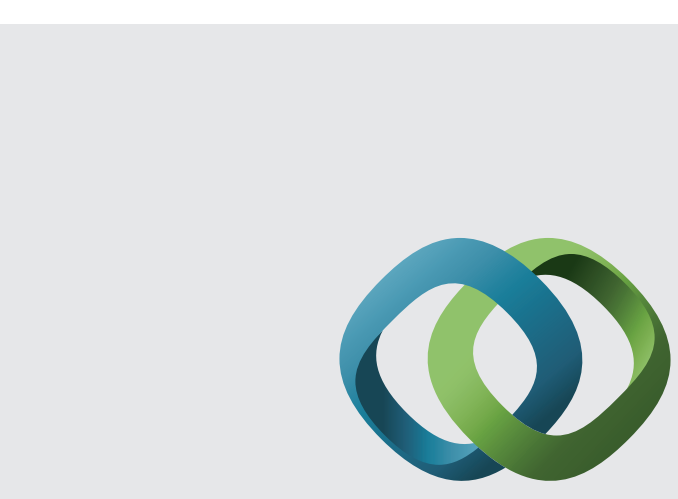

\section{Hindawi}

Submit your manuscripts at

http://www.hindawi.com
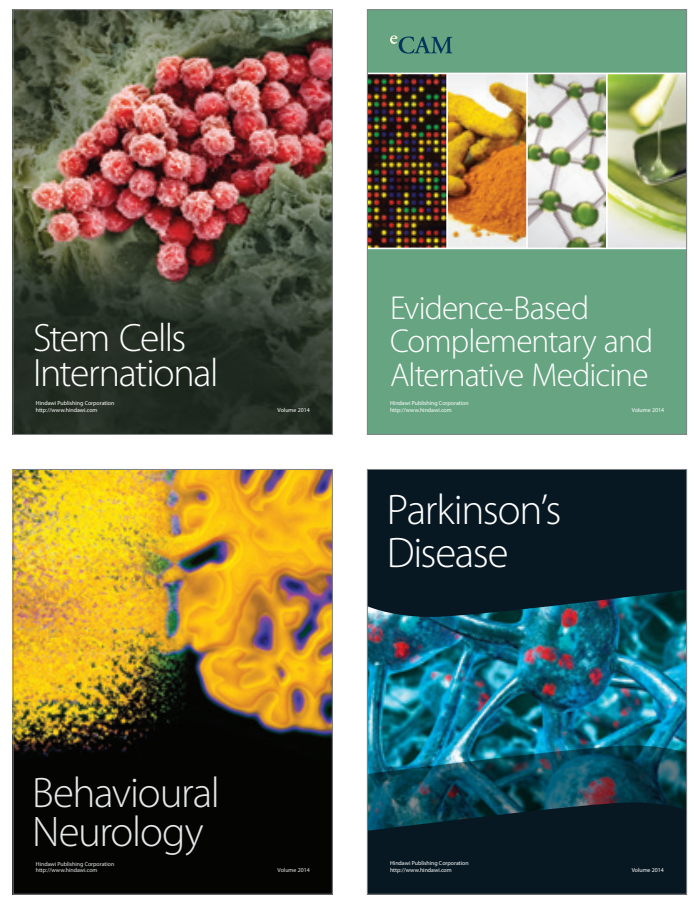
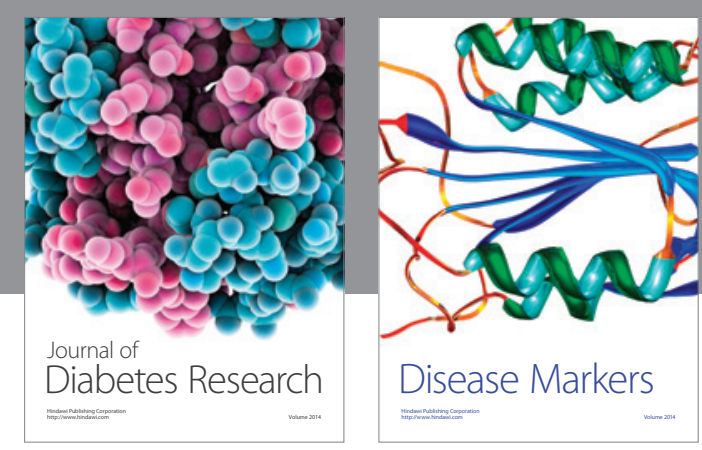

Disease Markers
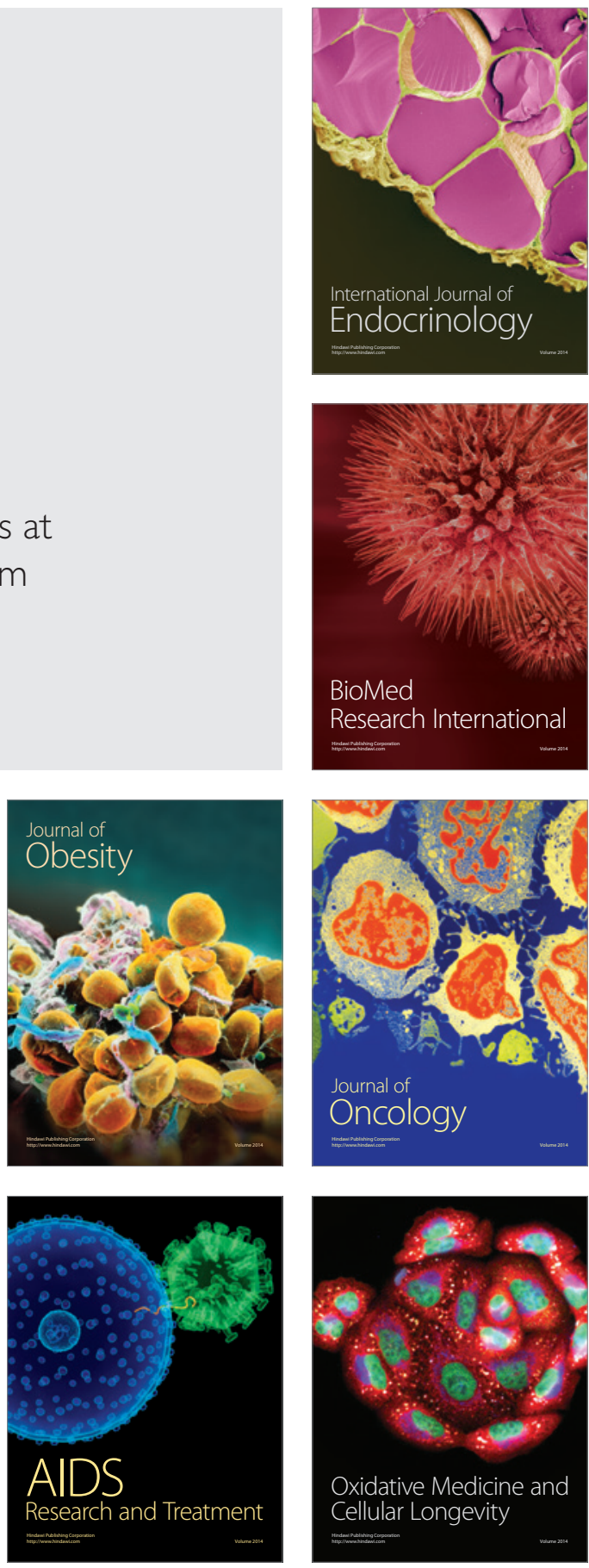